\title{
NEUROENDOCRINE TUMOR OF THE PANCREAS HEAD
}

\section{Tukhbatullin M.G., Yangurazova A.E., Galeeva Z.M., Khamzina F.T.}

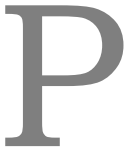

urpose. The article presents the case of diagnostics in a female patient, without specific complaints, with a neuroendocrine tumor of the pancreas head. Early recognition of the tumor during the ultrasound examination with the use of new technology of ultrasound shear-wave elastography made it possible to carry out further examination and timely treatment.

The early detection of neuroendocrine tumors still remains a complicated problem because of the large range of specialists to whom patients with tumors initially come. In a number of cases patients do not complain of anything or they have non-specific complains and most often they self thus losing the opportunity of timely early diagnostics and treatment.

The ultrasound examination is one of the cheapest, quickest and safest methods of diagnostics, which undoubtedly can be used as a screening method and with the use of the advanced technologies such as the ultrasound shear wave elastography can help to make the early diagnostics of tumors more precise.

Keywords: pancreatic neuroendocrine tumor, ultrasonography, ultrasound shear wave elastography, CT, PET

Corresponding author: Munir G. T., e-mail: munir.tuhbatullin@tatar.ru

For citation: Tukhbatullin M.G., Yangurazova A.E., Galeeva Z.M., Khamzina F.T. Neuroendocrine tumor of the pancreas head (a case report). REJR 2017; 7 (4):164-170. DOI:10.21569/2222-7415-2017-7-4-164-170.

Received: $\quad 11.10 .17 \quad$ Accepted: $\quad 30.10 .17$

\section{НЕЙРОЭНАОКРИННАЯ ОПУХОАЬ ГОЛОВКИ ПОАЖЕАУАОЧНОЙ ЖЕАЕЗЫ}

\author{
Тухбатулиин М.Г., Янгуразова А.Е., Галеева З.М., Хамзина Ф.Т.
}

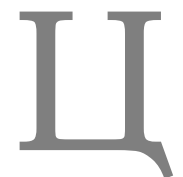

емь исследования. В статье представлен случай диагностики нейроэндокринной опухоли головки поджелудочной жемезы у пациентки без специфических жалоб. Ранняя диагностика опухоли на этапе ультразвукового исследования с применением новой технологии - ультразвуковой эластографии сдвиговой волной - позволила провести дальнейшее обследование и своевременное оперативное мечение пациентки.

Раннее выявцение нейроэндокринных опухолей остается сложной проблемой изза большого спектра специалистов, к которым первоначально обращаются больные с опухолью. В ряде случаев пациентов ничего не беспокоит или эти жалобы неспецифичны, пациенты чаще занимаются самолечением, что упускает возможности своевременной ранней диагностики и мечения.

Одним из самых дешевых, быстрых, безопасных методов диагностики явцяется ультразвуковое исследование, которое, несомненно, подходит в качестве метода скрининга, а при использовании таких новейших технологий, как ультразвуковая эмастография сдвиговой волной, позволяет сделать раннюю диагностику образований более точной.

Ключевые слова: нейроэндокринная опухоль поджелудочной железы, ультразвуковое исследование, ультразвуковая эластография сдвиговой волной, компьютерная томография, позитронно-эмиссионная томография. 
Контактный автор: Тухбатуммин М. Г., e-mail: munir.tuhbatullin@tatar.ru

Для иитирования: Тухбатуллин М.Г., Янгуразова А.Е., Галеева З.М., Хамзина Ф.T. Нейроэндокринная опухоль головки поджелудочной железы. REJR 2017; 7 (4):164170. DOI:10.21569/2222-7415-2017-7-4-164-170.
Статья получена:
11.10.17
Статья принята:
30.10 .17

$\mathrm{N}$

euroendocrine tumors (NETs) constitute a heterogeneous group of tumors with their origin in neuroendocrine cells of the embryological gut and belong to so called APUD system. They are capable of scavenging and decarboxylate amine precursors such as dopamine and serotonins. NETs occur in all organs with neuroendocrine cells [1]. In $1907 \mathrm{~S}$. Oberndorfer for the first time described neuroendocrine tumors under the term of "carcinoid" [2]. According to scientific literature the incidence of neuroendocrine tumors is estimated to be from 2 to 5 emergence diseases per 100000 people a year [3, 4].

Currently there are several classifications of neuroendocrine tumors: by embryogenesis, by tumor grade, by functionality, clinic-anatomic classification, histology classification and TNMclassification [1].

By embryogenesis (Williams and Sandler, 1963) tumors are unitized as foregut NETs (bronchi, the stomach, the pancreas, the duodenum), midgut NETs (the small intestine, the cecum, the appendix) and hindgut NETs (the colon and the rectum).

The functionality classification unitizes NETs as functional tumors with clinical symptoms, constituting $65-70 \%$ of all NETs, and nonfunctional ones without any clinical symptoms or with nonspecific symptoms, constituting about $30-35 \%$. The term "non-functional" is conditional as such tumors can produce a hormone in amounts insufficient for clinic onset or can produce a hormone which does not give specific symptoms that hampers diagnostics at the early stages of the disease. Quite frequently such tumors are revealed only when they, having grown to the big size from 3.5 to $20 \mathrm{~cm}$, compress tissues surrounding the organ. That is why NETs are quite often an incidental finding during another disease examinations [5].

According to different statistical data, the incidence of GEP-NETs is estimated to be $12-15$ cases per $1 \mathrm{mln}$ people. The pancreatic tumors amount to $70-80 \%$ of them. With the early NET diagnosis, the rate of survival of patients at fiveyears after radical surgery makes 80-100\% however quite often diagnostic examinations start only when there are metastases or development of tumor cachexia. Even large clinics have experience of treating no more than 100 of such patients [6, 7].

NETs can be characterized as unique tumors due to their slow growth and a favorable potential for survival even with metastases. Thus the assumption about the neuroendocrine tumor origin is very important for choosing the treatment tactics.

The choice of treatment tactics depends on the type and the grade of the tumor. In this case the classification of the WHO (2010) and the European NETs Association (ENETS, 2011) are used. The classification includes three classes depending on the hyperplastic activity index Ki-67 (See Table. 1).

The scientific literature gives different figures for the sensitivity of the tumor localization diagnosis methods: ultrasound- 15-70\% (depending on the size and localization of the tumor), MSCT - 80-92\%, MRT - 30-75\%, endo-ultrasound - 80-95\%, intraoperative ultrasound - 85-100\% [8].

Unfortunately the capabilities of the most accessible traditional ultrasound methods for diagnosing "silent" NETs are limited.

The ultrasound examination sensitivity is increased by new technologies in particular the shear-wave ultrasound elastography (SWE), which is sure-footedly introduces into the clinical practice $[9,10]$. It is known that pathological tissues are characterized by increased inelasticity and decreased deformation ability. High density or inelasticity of the tumor is considered as an indicator of its malignance. The SWE technique makes it possible to define the rigidity of a tumor under examination due to the ability to give qualitative and quantitative evaluation of the mechanical qualities indicators of the examined object. The qualitative analysis of the tumor density is carried out by evaluation of the cartogram of the area of interest while the quantitative analysis is made by evaluating the rigidity (elasticity) of the tissues under examination in numerical values $(\mathrm{kPa})$. The developers of the SWE technique have agreed that "soft" and "rigid" tissues are coded by different colors of the spectrum. The absence of color in the 
RUSSIAN ELECTRONIC JOURNAL OF RADIOLOGY

Табцица №1. Классификация ВОЗ (2010 г.) и ENETS (2011 г.).

\begin{tabular}{c|c|c|c|}
\hline Class & Name & Index Ki-67, \% & $\begin{array}{c}\text { Number of mitoses (10 } \\
\text { RFV) }\end{array}$ \\
\hline Grade 1 & Neuroendocrine tumor & $<$ & $2-20$ \\
\hline Grade 2 & Neuroendo rine tumor & $2-20$ & $>20$ \\
\hline Grade 3 & Neuroendocrine carcinoma & $>20$ & \\
\hline
\end{tabular}

tumor zone was given the name of the "black hole" phenomenon. It is explained by the desmoplastic reaction with formation of the collagen barrier along the tumor periphery $[11,12,13,14]$.

Due to scarcity of the given pathology and its complicated diagnostics we present to your attention a clinical case of detection of the NET of the head of the pancreas.

Clinical case. A 62 year-old female patient came to a gastroenterologist complaining of discomfort in the right hypochondria after meals and altered defecation pattern with a tendency to constipation. The gastroenterologist recommended the examination which included clinical and biochemical blood checks and ultrasound examination of the hepatobiliary system.

The clinical and biochemical blood checks did not show any lapses.

Ultrasonography of the hepatobiliary system was carried out in the department of the ultrasound diagnostics of the medical unit of the Kazan (Volga region) Federal University $(\mathrm{K}(\mathrm{V}) \mathrm{FU})$ with the use of the expert class ultrasound scanner Aixplorer (SuperSonic Imagine, France) in different regimes of ultrasound visualization and in the regime of ultrasound shear wave elastorgaphy by the convex probe with the frequency range of 1-6 $\mathrm{MHz}$.

The traditional ultrasound examination of the liver showed moderate steatosis without the damage of the liver angioarchitecture. Detected in the gull bladder there was one gull stone $12 \mathrm{~mm}$ in the longitudinal axis (long?). No dilatation of the liver and the pancreas ducts were detected. An iso-hypo echogenic round-shaped lump with clear even shape and with the size of $18 \times 15 \times 18$ $\mathrm{MM}$ and the dimension of $2.6 \mathrm{ml}$, which produced the effect of dorsal echo enhancement, was detected on the posterior surface of the pancreas closer to the pancreas unciform. The CDI regimeshoed it to be hypovascular (Fig. 1). The qualitative evaluation of the lump rigidity by the ultrasound shear wave elastography registered the phenomenon of the "black hole" that made it possible to suppose the probable malignancy of the tumor (Fig. 2).

Conclusion: Additional mass lesion of the head of the pancreas, diffuse changes of the liver, the gull stone.
The abdominal contrast-enhanced MSCT and endoscopic sonography were carried out as methods for getting more specific information.

The multispiral computed tomography (MSCT) of the abdomen and the retroperitoneum without intestinal enhancement per os with transcatheter bolus angiography did not show the increased size of the pancreas. The native tomograms on the background of dystrophic changes of the pancreas tail and body do not rule out the presence of a mass lesion with the density of $30+/-9.5 \mathrm{HU}$ in the dorsal part of the pancreas head (Fig. 3, 5). A mass lesion with well-defined wavy contours with the size of $2 \times 2 \times 1.8 \mathrm{~cm}$ and the dimension of $3.8 \mathrm{~mm}$ with heterogeneous contrast accumulation mostly intensive along the periphery was detected in the dorsal part of the pancreas head between the portal vein and the IVC during the arterial phase of contrast enhancement (Fig. 4a), the arteries coming up to the tumor were visualized and later the character of the tumor contrast did not change (Fig. 4b). No dilation of the Wirsung's duct was detected. No pathological changes of the pancreatic tissue or metastases in the liver were found. The adjacent blood vessels had well-defined even contours without contrast enhancement defects.

Densitometric values of the liver parenchyma are decreased to 38-41 HU. Intrahepatic bile ducts are not dilated. The common biliary duct is $5 \mathrm{~mm}$ in the pancreatic part and $7 \mathrm{~mm}$ by the portal fissure, its walls are not deformed. The portal and the splenic veins are not varicose. The gall bladder is of normal size with homogenous contents. No radiopaque stones were detected. Conclusion: CT- signs of hepatosis, a mass lesion of the head of the pancreas.

The endoscopic sonography of the bilipancreatic zone did not detect the increased size of the pancreas but detected a heterogeneous mass lesion with well-defined even contours with the size of $21 \times 18 \times 18 \mathrm{~mm}$ and the dimension of $4.2 \mathrm{~mm}$ in the pancreas head closer to the isthmus. The Wirsung's duct is not dilated.

A single lymph node with the size of $9 \times 5 \mathrm{~mm}$ with maintained layers differentiation, which in certain projections in adjacent of the confluence of the portal vein near the common bile duct. The common biliary duct is not dilated. A $12 \mathrm{~mm}$ 


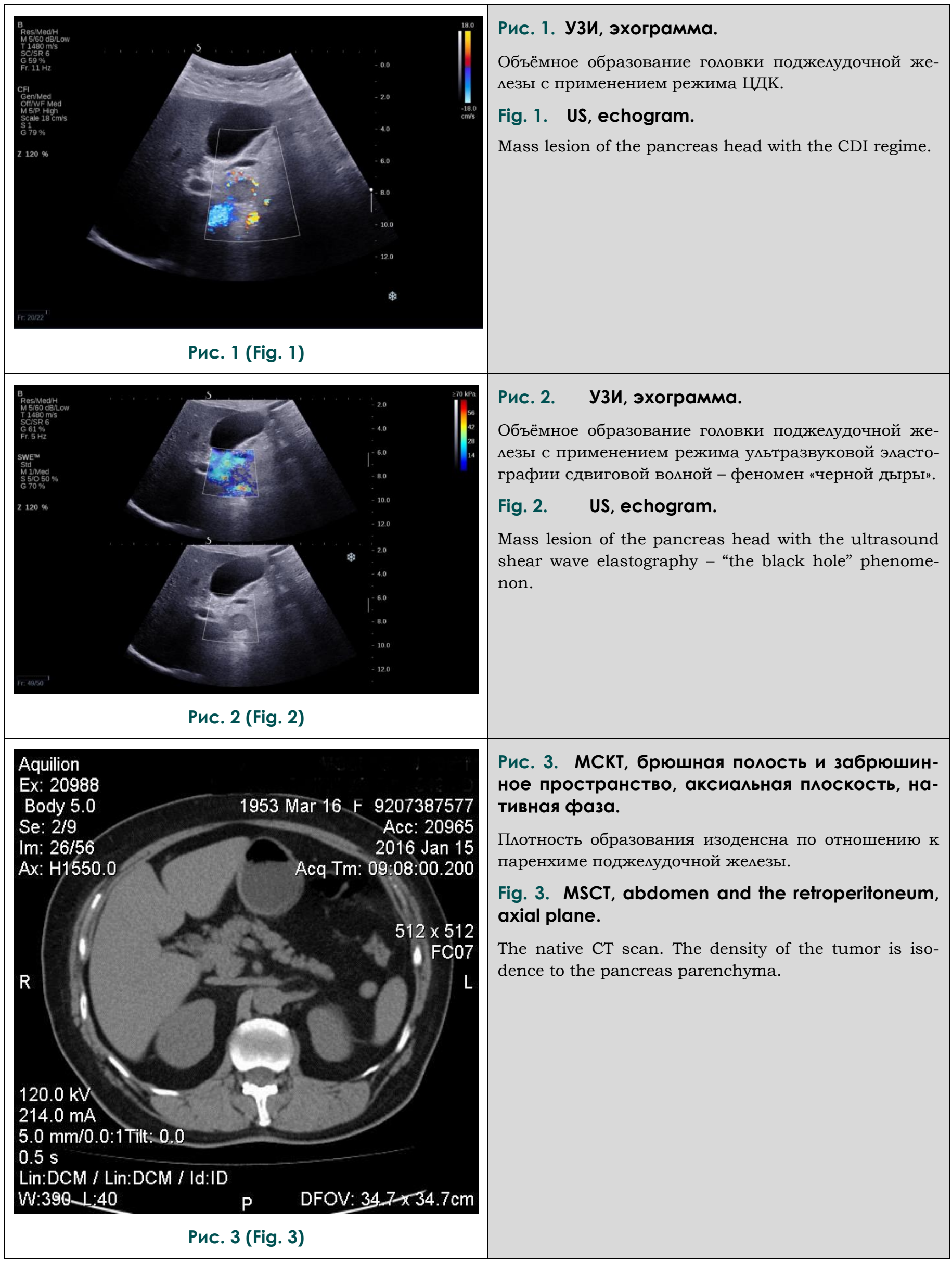




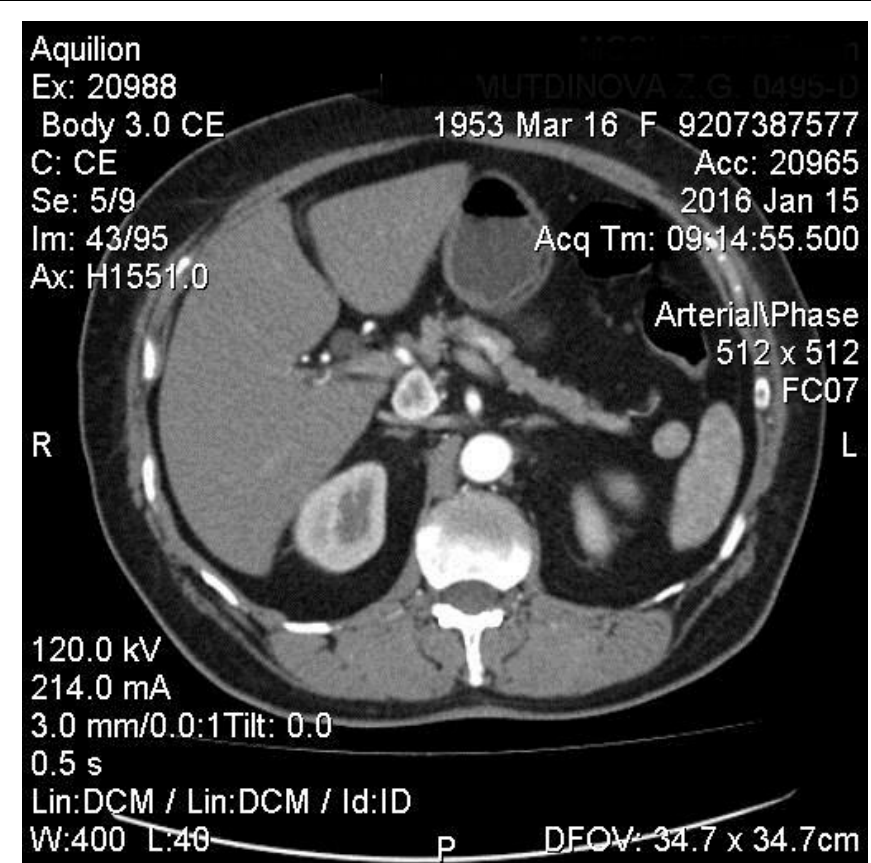

Рис. 4 a (Fig. 4 a)

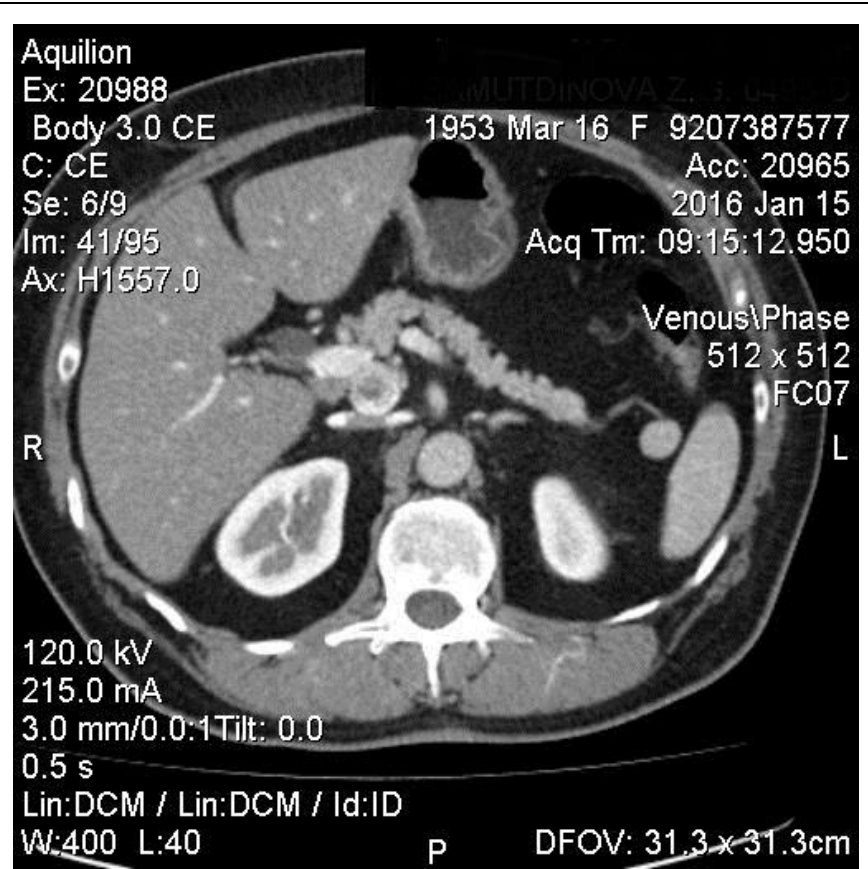

Рис. 46 (Fig. 4 б)

Рис. 4. МСКТ, брюшная полость и забрюшинное пространство, аксиальная плоскость, 4-хфазное контрастное усиление.

а) Артериальная фаза. Ткань образования активно накапливает контрастное вещество, в большей степени по периферии.

б) Поздняя артериальная фаза. Отмечается постепенное вымывание контраста.

Fig. 4. MSCT, abdomen and the retroperitoneum, axial plane. The 4-phase contrast enhancement.

a) The arterial phase. The tumor tissue actively cumulates the contrast mostly in the periphery.

b) Late arterial phase. The gradual contrast wash-out is registered.

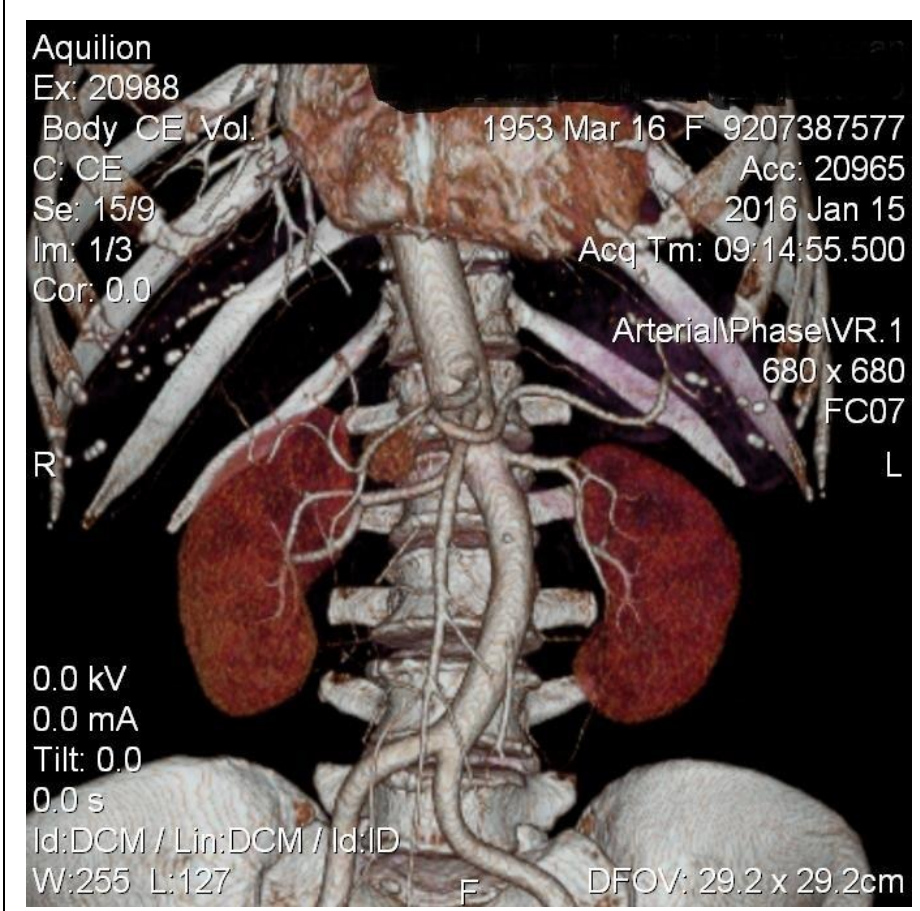

Рис. 5 (Fig. 5)
РИс. 5. 3D-моАель, образование головки поАжелуАОчной железы.

Fig. 5. 3D-model, mass lesion of the pancreas head. 
stone in the longitudinal axis was detected in the gull bladder.

Doctor's opinion: mass lesion of the pancreas head (Susp. mal), lymphadenopathy, cholecystolithiasis.

Following the results of the examinations the patient was referred to the Regional Clinical Cancer Center (RCCC). At the consultation the surgeon-oncologist recommended additional examinations: identification of the carcinoembrional antigen and of the pancreas carcinoma cancerspecific marker CA $19-9$ as well as the PET/CT examination.

The results of the laboratory diagnostics showed that the level of the carbohydrate antigen (the marker of the pancreas carcinoma CA-19-9) in blood was $6.97 \mathrm{UA} / \mathrm{ml}$ (with the reference values less than 27), the level of carcinoembrional antigen was $1.34 \mathrm{ng} / \mathrm{ml}$ (with the reference values less than $4.7 \mathrm{ng} / \mathrm{ml}$ )

During the PET/CT of the entire body with the use of $18 \mathrm{FDG}$, the series of scans examining the metabolism of glucose in the abdomen and the lower pelvis detected the FDG hyperfixation locus with SUVthr - 6.43 and SUVmax - 15.32, corresponding to the round-shaped mass lesion in the pancreas head (detected earlier by the X-ray CT with contrast enhancement).

The examination of metabolism of glucose on the series of scans of the head (from the orbit level) and the neck, the chest and the lung parenchyma and the skeletal system did not show any loci of the pathological FGD accumulation. The lungs did not have any local or infiltrative changes. The physiological (normal) accumulation of the imaging agent was in the oropharynx, the left ventricle myocardium, the stomach walls, the pyelocaliceal system of both kidneys and fragmentarily along the colon and the urinary bladder.

Doctor's opinion: PET/CT symptoms of the pathological metabolically active process with the involvement of the pancreas head with high prob-

\section{References:}

1. Bokhyan V.Y., Beltzevich D.G., Vashakmadze L.A., Gakhramanov A.D., Gorbunova V.A., Delektorskaya V.V., Yegorov A.V., Komov D.V., Kuvshinov Y.P., Lukyanchenko A.B., Lyubimova N.V., Markovich A.A., Orel N.F., Patyutko Y.I., Polotskiy B.E., Sinyukova G.T., Stilidi I.S., Ungiadze G.V., Khomyakov V.M., Chekini A.K., Cheremisov V.V., Shiryaev S.V.. Clinical recommendation on neuroendocrine tumors treatment. Moscow, 2014. 5-6 p.

2. Oberndorfer S. Karzinoide Tumoren des Dundarms. Frankf $Z$ Patholint. 1907; 1: 425-432.

3. Yegorov V.I., Kucheryavyy Y.A.. Pancreas diseases. Moscow. Trimedia Content, 2014. 46 p.

4. Yao J.C., Hassan M., Phan A. et al. One hundred years after "carcinoid": epidemiology of and prognostic factors for neuroendocrine tumors in 35,825 cases in the United States. J Clin Oncol. 2008; 26 (18): 3063-3072. ability of malignancy.

Following the results of the examination, the patient was admitted to the abdominal department of the RCCC where she underwent surgical treatment: laparotomy, the pancreas resection.

The histological and the IHC examinations of the resected material were done.

The histological test has shown the tumor of the pancreas with trabecular structure. The histological picture showed the neuroendocrine tumor. Two mitotic figures / $10 \mathrm{HPF}$. The IHC test has shown: IHC 1346: the tumor was synaptophysin and chromogranin positive. Index ki67 $=10 \%$. Ds: neuroendocrine cancer, G2. At the discharge the patient was given recommendations about followup and treatment.

\section{Conclusions.}

Representation of this clinical case is of great diagnostic and clinical interest. The early detection of neuroendocrine tumors still remains a complicated problem because of the large range of specialists to whom patients with tumors initially come. In a number of cases patients do not complain of anything or they have non-specific complains and most often they self- medicate by taking enzymes and exercising phytotherapy thus losing the opportunity of timely early diagnostics and treatment.

The ultrasound examination is one of the cheapest, quickest and safest methods of diagnostics, which undoubtedly can be used as a screening method and with the use of the advanced technologies such as the ultrasound shear wave elastography can help to make the early diagnostics of tumors more precise.

\section{Source of financing and conflict of inter-} ests.

Authors of this article confirmed lack of financial support of a research and conflict of interests about which it is necessary to report.

5. Martyn C., Larry K. Neuroendocrine tumors. The doctor's manual. Moscow, practical medicine, 2010. 9-131.

6. Katerlina I.R., Vlasova E.V., Dobrov S.L., Marchenko A.A. A case of ultrasound diagnostocs of the non-functioning neuroendocrine tumor of the pancreas. Sonoase ultrasound. 2012; 24: 82-88.

7. Pinskiy S.B., Beloborodov V.A., Batoroyev Y.K., Dvornichenko V.V. Neuroendocrine tumors of the pancreas. Siberian medical journal. 2013; 5: 12-16.

8. Chernousov A.F., Yegorov A.V., Musayev G.K., Fominykh E.V., Kondrashin S.A., Vasilyev I.A., Parnova V.A., Anisimova O.V. Neuroendocrine tumors of the pancreas: 30-year experience of the clinics of departmental surgery after N.N. Burdenko. Surgery. 2013; 7: 13-19.

9. Bastrakova A.E., Galeeva Z.M., Tukhbatullin M.G. Possibilities of complex echography in the early diagnosis of hepatic 


\section{RUSSIAN ELECTRONIC JOURNAL OF RADIOLOGY}

steatosis. Practical medicine. 2016; 2 (94): 48-50.

10. Tukhbatullin M.G., Yangurazova A.E., Galeeva Z.M. Complex diagnostic ultrasound in the assessment of the liver in patients with nonalcoholic fatty liver disease on the background of treatment. Practical medicine. 2016; 9 (101): 74-77.

11. Zykin B.I., Postnova N.A., Medvedev M.E. Elastography: the anatomy of the method. Radiology diagnostics, radiology therapy. 2012; 2: 107-113.

12. Postnov N.A., Vasilyev A.Y., Zykin B.I., Pavlinova E.S., Vyklyuk M.V. The shear wave elastography: possibilities of dif- ferential diagnostics of local and diffuse changes in different organs and tissues. Bulletin of $X$-ray radiography and radiology. 2011; 2: 29-34.

13. Ophir J. et al. Elastography: a quantitative method for imaging the elasticity of biological tissues. Ultrasonic Imaging. 1991; 13: 111-34.

14. Athanasiou A. et al. Breast Lesions: Quantitative Elastography with Supersonic Shear Imaging - Preliminary Results. Radiology. 2010; 256 (1): 297 - 303. 